\title{
Healthy CD4+ $T$ lymphocytes are not affected by targeted therapies against the PI3K/Akt/mTOR pathway in T-cell acute Iymphoblastic leukemia
}

\author{
Ayman A.M. Alameen ${ }^{1,2, *}$, Carolina Simioni ${ }^{1, *}$, Alberto M. Martelli ${ }^{3}$, Giorgio Zauli ${ }^{1}$, \\ Simona Ultimo ${ }^{1}$, James A. McCubrey ${ }^{4}$, Arianna Gonelli ${ }^{1}$, Giorgia Marisi ${ }^{5}$, Paola \\ Ulivi $^{5}$, Silvano Capitani ${ }^{1,6}$, Luca M. Neri ${ }^{1}$ \\ ${ }^{1}$ Department of Morphology, Surgery and Experimental Medicine, University of Ferrara, Ferrara, Italy \\ ${ }^{2}$ Department of Chemical Pathology, Faculty of Medical Laboratory Sciences, University of Khartoum, Khartoum, Sudan \\ ${ }^{3}$ Department of Biomedical and Neuromotor Sciences, University of Bologna, Bologna, Italy \\ ${ }^{4}$ Department of Microbiology \& Immunology, Brody School of Medicine, East Carolina University, Greenville, NC, USA \\ ${ }^{5}$ Biosciences Laboratory, Istituto Scientifico Romagnolo per lo Studio e Cura dei Tumori (IRST) IRCCS, Meldola, Italy \\ ${ }^{6}$ LTTA Center, University of Ferrara, Ferrara, Italy \\ *These authors have contributed equally to this work \\ Correspondence to: Luca M. Neri, email: luca.neri@unife.it \\ Silvano Capitani, email: silvano.capitani@unife.it
}

Keywords: Tlymphocytes, PI3K/AKt/mTOR signaling, T-acute lymphoblastic leukemia, targeted therapies, autophagy

Received: May 05, 2016

Accepted: July 11, 2016

Published: August 1, 2016

\section{ABSTRACT}

An attractive molecular target for novel anti-cancer therapies is the phosphatidylinositol 3-kinase (PI3K)/Akt/mammalian target of rapamycin (mTOR) pathway which is commonly deregulated in many types of cancer. Nevertheless, the effects of PI3K/Akt/mTOR inhibitors on T lymphocytes, a key component of immune responses, have been seldom explored. In this study we investigated the effects on human CD4+ T-cells of a panel of PI3K/Akt/mTOR inhibitors: BGT226, Torin-2, MK2206, and ZSTK474. We also assessed their efficacy against two acute leukemia $T$ cell lines. T lymphocytes were stimulated with phytohemagglutinin. Inhibitor effects on cell cycle and apoptosis were analyzed by flow cytometry, while cytotoxicity was assessed by MTT assays. In addition, the activation status of the pathway as well as induction of autophagy were analyzed by Western blotting.

Quiescent healthy T lymphocytes were unaffected by the drugs whereas mitogenstimulated lymphocytes as well as leukemic cell lines displayed a cell cycle block, caspase-dependent apoptosis, and dephosphorylation of key components of the signaling pathway. Autophagy was also induced in proliferating lymphocytes and in JURKAT and MOLT-4 cell lines. When autophagy was inhibited by 3-methyladenine or Bafilomycin A1, drug cytotoxicity was increased, indicating that autophagy is a protective mechanism.

Therefore, our findings suggest that PI3K/Akt/mTOR inhibitors preserve lymphocyte viability. This is a valuable result to be taken into account when selecting drugs for targeted cancer therapy in order to minimize detrimental effects on immune function.

\section{INTRODUCTION}

The phosphatidylinositol-3 kinase/Akt/mTOR (PI3K/Akt/mTOR) signal transduction pathway is activated by several stimuli regulating cell proliferation and survival, translation, autophagy and metabolism. Several members of the PI3K/Akt/mTOR cascade play crucial roles in maintaining cell homeostasis under normal physiological conditions [1]. 
PI3K comprises a family of lipid kinases which phosphorylate the 3-OH group of inositol lipids. They are classified into Class I, II, and III based on primary structure and regulation. Class I PI3Ks are heterodimeric enzymes, displaying a catalytic and a regulatory subunit. The catalytic subunits comprise $\mathrm{p} 110 \alpha, \mathrm{p} 110 \beta, \mathrm{p} 110 \gamma$, and $\mathrm{p} 110 \delta$, which associate in different ways with the regulatory subunits (p85 $\alpha, \mathrm{p} 85 \beta$, and $\mathrm{p} 55 \gamma, \mathrm{p} 101, \mathrm{p} 84$, and p87PIKAP) [2].

Akt requires phosphorylation of both Ser473 and Thr308 amino acidic residues to be fully activated and regulates several downstream, processes including positive activation/regulation of mTOR functions [3].

mTOR is a $289-\mathrm{kDa}$ serine/threonine protein kinase, which regulates cell growth. mTOR is the catalytic subunit of two multi-protein complexes: complex 1 (mTORC1) and mTOR complex 2 (mTORC2).

mTORC1 is responsive towards growth factors, nutrients, energy, or oxidative stress and phosphorylates 4E-BP1 and S6K which are important for protein translation. mTORC2 phosphorylates Akt at the Ser473 residue for complete activation of the $\mathrm{PI} 3 \mathrm{~K} / \mathrm{Akt} / \mathrm{mTOR}$ pathway. Other downstream substrates of mTORC2 include PKC [4, 5].

T-cell acute lymphoblastic leukemia (T-ALL) is a malignant disease of $\mathrm{T}$ lymphocytes progenitors, characterized by the accumulation of immature undifferentiated thymocytes that acquired multiple genetic aberrations. This results in a poor prognosis, especially for relapsed patients [6]. Aberrant regulation of the PI3K/ $\mathrm{Akt} / \mathrm{mTOR}$ axis often confers a proliferative advantage to tumor cells and contributes to the development of drugresistance mechanisms.

At present only class I PI3Ks have been shown to be associated with cancer: indeed PIK3CA, the gene which encodes for $\mathrm{p} 110 \alpha \mathrm{PI} 3 \mathrm{~K}$, is mutated in a variety of tumor types [7-9]. Mutations of the p85 subunit have also been shown to be oncogenic $[10,11]$.

The PI3K/Akt/mTOR signaling pathway is frequently up-regulated in T-ALL. This is due to several causes, including phosphorylation, oxidation and gene mutation/deletion, which affect PTEN phosphatase function $[12,13]$.

Thus, targeting the PI3K/Akt/mTOR axis represents an attractive novel therapeutic strategy for T-ALL. However, which drug against one or more members of this signaling network can achieve the greater efficacy is still an open question.

To address this issue we employed a pharmacological approach aimed to compare the efficacy of four drugs, one targeting mTORC1/C2 (Torin-2) [14, 15], one against PI3K/mTORC1/C2 (NVP-BGT226) $[16,17]$, one targeting Akt (MK-2206) [18-21], and the fourth one directed against all the class I PI3K isoforms (ZSTK474) [22-24].

Only a limited number of studies have analyzed the impact of PI3K/Akt/mTOR network inhibitors on human T-cells. The few published data have been mainly focused only on PI3K inhibitors, such as wortmannin and LY294002 [25] or pan class I PI3K inhibitors [26] or drugs

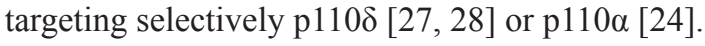

Drugs targeting the PI3K/Akt/mTOR cascade can interfere with diverse biologic processes also in healthy cells, thus rising concerns about their use in therapeutics. In particular, it is essential to gain knowledge about their effect on immune cells, as it would be desirable to preserve patient's immunity.

The aim of this study was to analyze the effect of the four above mentioned drugs in human primary $\mathrm{CD}^{+}$ T-cells. most of these inhibitors are currently being tested in clinical trials. We have assessed the anti-tumor activity of NVP-BGT226 (BGT226), Torin-2, MK-2206 and ZSTK474 in human T-ALL cells and studied their effects on healthy $\mathrm{CD}^{+} \mathrm{T}$-cell, induced or not to proliferate.

Our findings suggested that, to minimize off-target effects and to benefit from the optimal response, selective inhibitors targeting the PI3K/Akt/mTOR may represent a new promising treatment for T-ALL patients, since they showed a strong cytotoxicity against leukemic T-cells or T-lymphocytes stimulated to proliferate, whereas they did not compromise viability of quiescent healthy $\mathrm{CD} 4^{+} \mathrm{T}$ lymphocytes.

\section{RESULTS}

\section{Activation status of $\mathrm{PI}$ KK/Akt/mTOR pathway in healthy $\mathrm{CD}^{+} \mathrm{T}$ lymphocytes and T-ALL cell lines}

By Western blot analysis, we wanted to evaluate the baseline levels of some key proteins involved in the $\mathrm{PI} 3 \mathrm{~K} / \mathrm{Akt} / \mathrm{mTOR}$ axis in both unstimulated and stimulated healthy $\mathrm{CD} 4^{+} \mathrm{T}$ lymphocytes and in T-ALL cells (MOLT4 and JURKAT cell lines). We decided to study $\mathrm{CD}^{+}$ cells as they are helper cells that play important roles for regulating immunological responses [29].

Stimulated T lymphocytes, MOLT-4 and JURKAT cells showed a relevant phosphorylation at Ser473 and Thr308 of Akt and at Ser235/236 of ribosomal protein S6 kinase, a readout of mTORC1 activity. The same cell types also displayed mTOR phosphorylation at Ser2448 and Ser2481 residues, readout for mTORC1 and mTORC2, respectively. The phosphorylation was not evident in unstimulated $\mathrm{CD}^{+}{ }^{+} \mathrm{T}$ lymphocytes (Figure 1).

\section{BGT226, Torin-2, MK-2206 and ZSTK474 are cytostatic and cytotoxic to stimulated T lymphocytes and T-ALL cell lines}

BGT226 is an ATP-competitive dual PI3K/ mTORC1/2 inhibitor used for treatment of advanced solid tumors [30,31]. As previously reported by our group, it was cytotoxic to a panel of hepatocarcinoma cell lines, 
under both normoxia and hypoxia conditions [32]. Torin-2 potently targets $\mathrm{mTORC} 1 / 2$, and is an effective inhibitor of ATM, ATR and DNA-PK [14].

The efficacy of MK-2206 as well as ZSTK474 have been tested in various preclinical models of human cancers, including leukemias [3, 19, 22, 33-36].

To determine how these inhibitors could affect the viability of the primary $\mathrm{CD}^{+} \mathrm{T}$ lymphocytes (both unstimulated and stimulated) and T-ALL cells, we performed MTT assays. Cells were incubated for $48 \mathrm{~h}$ with the inhibitors, and then cell survival was analyzed (Figure 2A and Table 1). Except for the unstimulated $\mathrm{T}$ lymphocytes, BGT226 and the mTORC1/2 inhibitor Torin-2 turned out to be the most powerful drugs in these cells. For unstimulated T lymphocytes, there was no relevant inhibition for both drugs $\left(\mathrm{IC}_{50}>2 \mu \mathrm{M}\right)$. For BGT226, cell viability impairment was more evident in T-ALL cell lines, with $\mathrm{IC}_{50}$ values of $0.08 \mu \mathrm{M}$ for JURKAT, $0.06 \mu \mathrm{M}$ for MOLT-4 and $1.61 \mu \mathrm{M}$ for stimulated T lymphocytes. Similar results were obtained with Torin-2, with $\mathrm{IC}_{50}$ values of $0.1 \mu \mathrm{M}$ for JURKAT and MOLT-4 and 1.8 $\mu \mathrm{M}$ for stimulated T-cells.

Regarding MK-2206, the cells displayed higher values of $\mathrm{IC}_{50}(>2 \mu \mathrm{M})$ except for MOLT-4 cells with an $\mathrm{IC}_{50}$ of $1.58 \mu \mathrm{M}$. For ZSTK474 the same resistance for the primary $\mathrm{T}$ lymphocytes was observed, while in MOLT-4 and JURKAT cell lines the sensitivity of the drug was evident, with $\mathrm{IC}_{50}$ values of $0.52 \mu \mathrm{M}$ and $0.95 \mu \mathrm{M}$, respectively. The $\mathrm{IC}_{50}$ of stimulated $\mathrm{T}$ lymphocytes was $>2 \mu \mathrm{M}$ (Table 1).
To further assess the cytotoxicity of inhibitors targeting $\mathrm{PI} 3 \mathrm{~K} / \mathrm{Akt} / \mathrm{mTOR}$, we analyzed the changes in cell viability using flow cytometry after treatment with $1 \mu \mathrm{M}$ of each drug for $48 \mathrm{~h}$. Compared to MK-2206 and ZSTK474, BGT226 and Torin-2 displayed higher cytotoxic effect on stimulated T lymphocytes, MOLT-4 and JURKAT cells. None of the drugs affected the viability of unstimulated $\mathrm{CD}^{+}{ }^{+} \mathrm{T}$ lymphocytes (Figure 2B). For all these reasons, for the subsequent experiments we decided to test only BGT226 and Torin-2.

Considering the important role of the PI3K/ Akt/mTOR signaling cascade in regulating cell proliferation [37], we investigated the effect of the drugs on cell cycle progression. Cells were treated with the two most effective drugs (BGT226 and Torin-2) for $24 \mathrm{~h}$ and stained with Propidium Iodide (PI) for flow cytometric analysis. A concentration dependent increase of cells in the $\mathrm{G}_{0} / \mathrm{G}_{1}$ phase of the cell cycle and a concomitant decrease in cells of both $S$ and $G_{2} / M$ phase were observed (Figure 3 ). The increase was highly significant in stimulated $T$ lymphocytes, MOLT-4 and JURKAT cells, whereas did not occur in unstimulated T lymphocytes.

\section{BGT226 and TORIN-2 down-regulate the PI3K/Akt/mTOR pathway in stimulated $\mathrm{CD4}^{+} \mathrm{T}$ lymphocytes and T-ALL cells}

To determine whether BGT226 and Torin-2 could affect factors that promote cell survival, stimulated $\mathrm{T}$ lymphocytes, MOLT-4 and JURKAT cells were treated

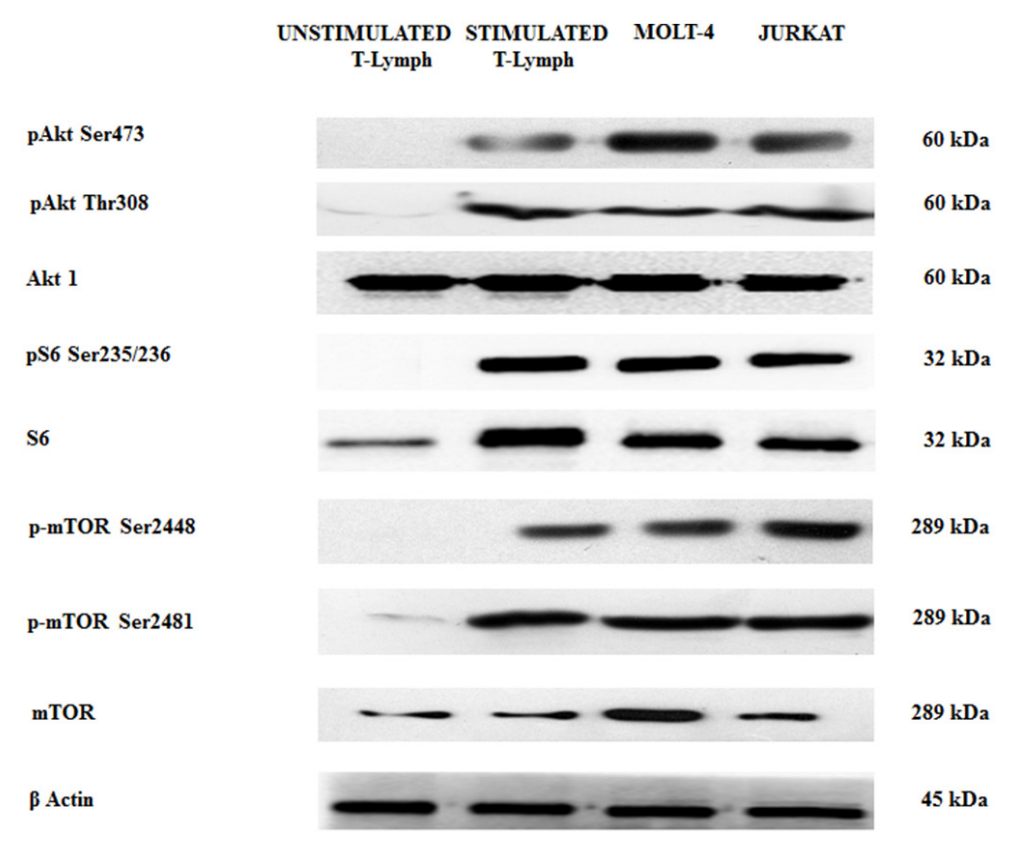

Figure 1: Expression and phosphorylation status of Akt, mTOR and the S6 downstream target in primary (unstimulated and stimulated) CD4 ${ }^{+}$T lymphocytes and T-ALL cell lines. Western blot analysis of primary T lymphocytes and T-ALL cell lines to detect the expression and phosphorylation levels of Akt, mTOR, and S6 protein. Twenty-five $\mu \mathrm{g}$ of protein were blotted on each lane. $\beta$-actin was revealed as loading control. 
with increasing concentrations of BGT226 and Torin-2 for $2 \mathrm{~h}$ and then analyzed by Western blot (Figure 4). The inhibition of mTORC2 had a readout in Ser473 Akt dephosphorylation and it was observed in all cell types treated with BGT226 and Torin-2 starting from the lowest concentrations. Thr308 Akt was dephosphorylated by both drugs, as was GSK3 $\beta$ Ser21/9, an Akt substrate. The mTORC1 substrate S6 was completely dephosphorylated on Ser235/236 residue, already at the lowest concentrations of BGT226 and Torin-2. Both drugs downregulated the phosphorylation levels of mTOR at both Ser2448 and Ser2481 residues [38].
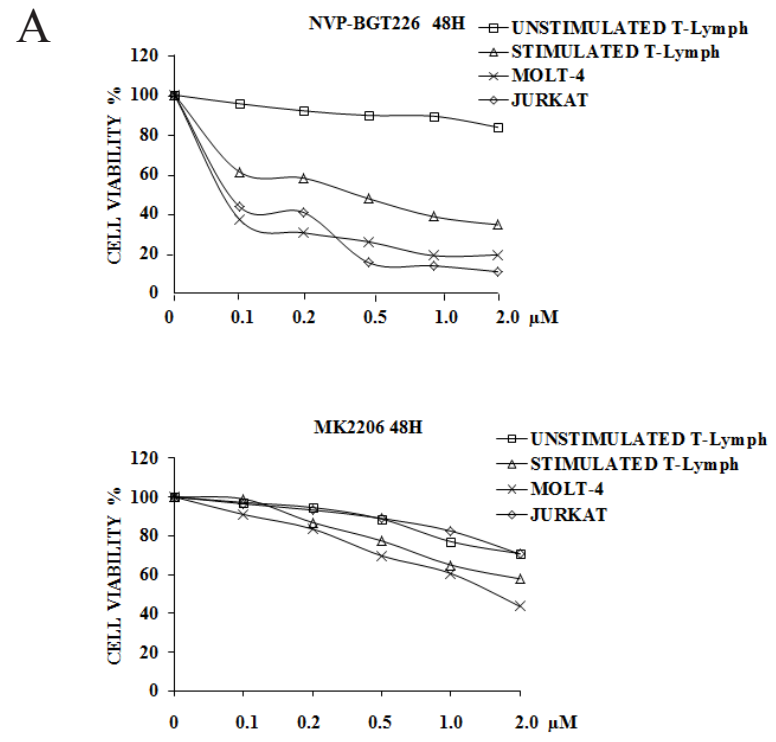

\section{BGT226 and TORIN-2 induce autophagy}

Autophagy plays a very important role in cell physiology, either as a form of cell death or as a protective mechanism against apoptosis $[39,40]$. Therefore, there is a growing interest on the pharmacological approaches aimed to regulate autophagy, which represent a new area for the development of therapeutics protocols. Moreover, over the last few years various papers described the occurrence of autophagy in acute leukemia cells [reviewed in 42]. To find out if BGT226 and Torin-2 could induce autophagy, we analyzed the expression levels of microtubule-associated
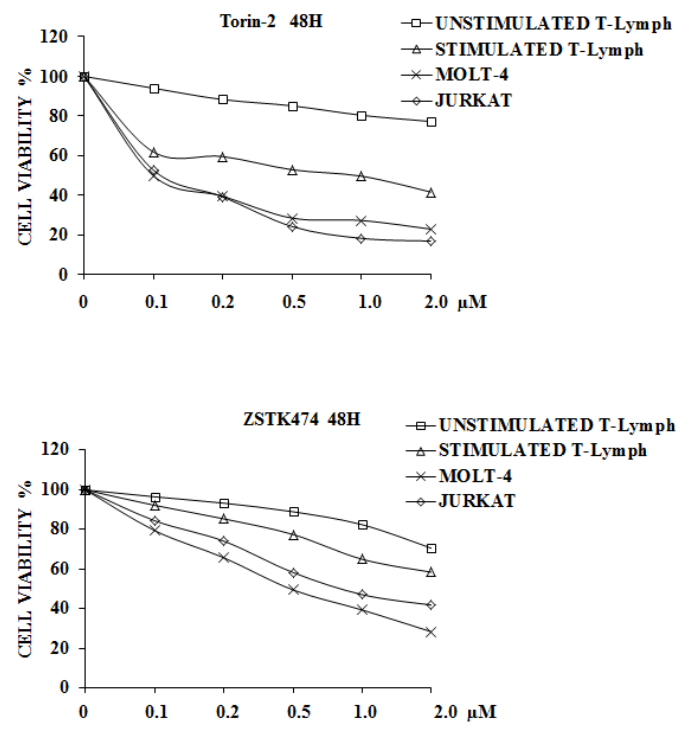

B

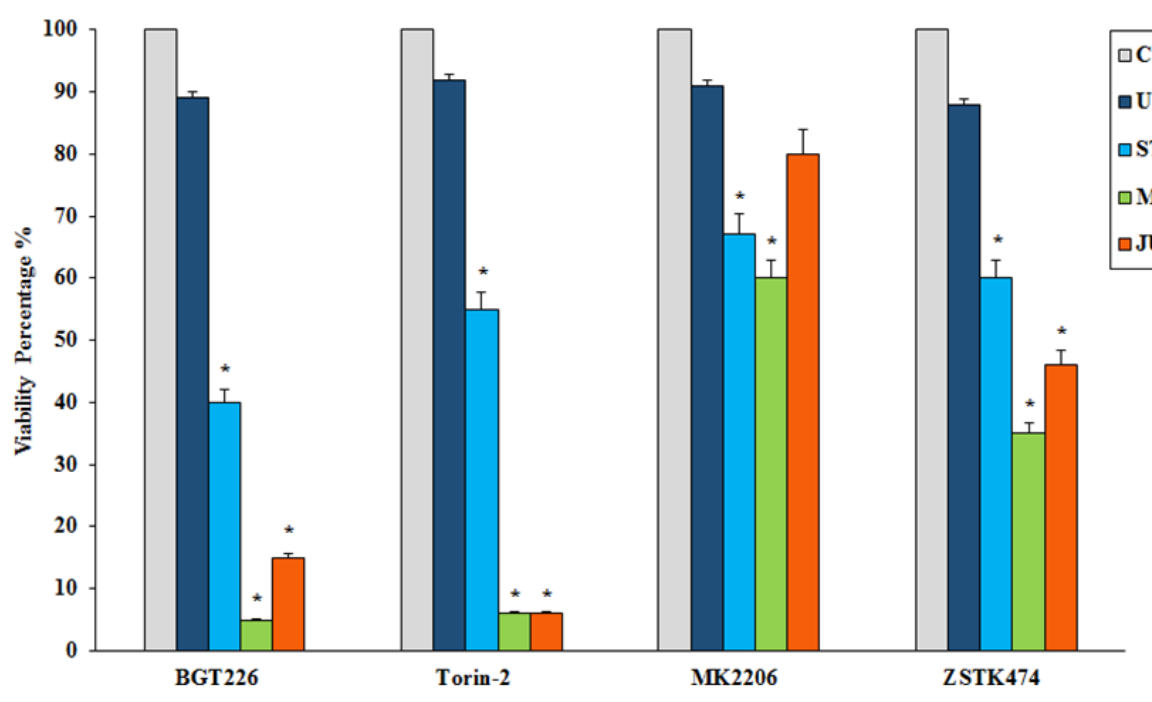

Figure 2: Cytotoxicity of BGT226, Torin-2, MK-2206 and ZSTK474 in primary T lymphocytes, MOLT-4 and JURKAT cell lines. A. MTT assays of primary T lymphocytes and T-ALL cell lines treated with increasing concentrations of BGT226, Torin-2, MK-2206 and ZSTK474 for 48 h. SD was less than 7\%. One representative experiments of three is shown. B. Viability of primary T lymphocytes, MOLT-4 and JURKAT cell lines treated for $48 \mathrm{~h}$ with $1 \mu \mathrm{M}$ BGT226, Torin-2, MK-2206 and ZSTK474. Asterisks indicate statistically significant differences with respect to untreated cells $(* \mathrm{p}<0.05)$. 
Table 1: $\mathrm{IC}_{50}$ values of cells treated for 48 hours with different drugs

\begin{tabular}{|c|c|c|c|c|}
\hline & BGT226 & Torin-2 & MK2206 & ZSTK474 \\
\hline $\begin{array}{l}\text { UNSTIMULATED } \\
\text { T-Lymphocytes }\end{array}$ & $>2.0$ & $>2.0$ & $>2.0$ & $>2.0$ \\
\hline $\begin{array}{l}\text { STIMULATED } \\
\text { T-Lymphocytes }\end{array}$ & 1.61 & 1.8 & $>2.0$ & $>2.0$ \\
\hline MOLT-4 & 0.06 & 0.1 & 1.58 & 0.52 \\
\hline JURKAT & 0.08 & 0.1 & $>2.0$ & 0.95 \\
\hline
\end{tabular}

Values are expressed in $\mu \mathrm{M}$

protein 1 light chain 3 LC3A/B I (non-lipidated form) and of its conjugated form LC3A/B II (lipidated). After $24 \mathrm{~h}$ of treatment with BGT226 and Torin-2, the unstimulated $\mathrm{T}$ lymphocytes showed no expression of LC3A/B II which, in contrast, increased gradually in a concentration dependent manner, for both drugs, especially in MOLT4 and JURKAT cells (Figure 5A). We also analyzed the expression of p62, another marker of autophagy. p62 levels decreased in response to drug treatments in stimulated $\mathrm{CD}^{+}$lymphocytes and leukemic cell lines, but remained unchanged in quiescent T-cells (Figure 5A).

To establish whether autophagy was either a cell death or survival mechanism, we employed the autophagy inhibitor 3-Methyladenine (3-MA), which inhibits autophagy by blocking class III PI3K [41]. We also used Bafilomycin A1, another autophagy inhibitor, to further assess the mechanism of drug cytotoxicity. We treated stimulated T lymphocytes and JURKAT cells with BGT226, Torin-2, 3-MA or Bafilomycin A1 alone and in combination for $24 \mathrm{~h}$. Results showed that 3-MA or Bafilomycin A1 alone did not affect cell viability, even at high concentrations (10 $\mu \mathrm{M}$ or $4 \mu \mathrm{M}$, respectively). On the other hand, when 3-MA or Bafilomycin A1 were administered with $0.25 \mu \mathrm{M}$ BGT226 or Torin-2, the cells became more sensitive to the cytotoxic effect of both drugs (Figure 5B and 5C). These findings highlighted a protective role of autophagy from cytotoxicity induced by BGT226 and Torin-2 in stimulated T-lymphocytes and in JURKAT cell line.

\section{Apoptosis is required for mediating BGT226 and Torin-2 cytotoxicity}

Previous studies documented that in T-ALL cells BGT226 could induce apoptosis [42]. In addition, our recent results demonstrated that Torin- 2 is effective in Pre-B precursor-ALL cells [43]. In order to establish whether decreased viability was due to apoptosis, unstimulated and stimulated $\mathrm{T}$ lymphocytes as well as MOLT4 and JURKAT cell lines, were incubated with increasing concentrations of BGT226 and Torin-2 for $24 \mathrm{~h}$, then Western blot was performed for analyzing the expression levels of poly(ADP-ribose)polymerase (PARP). The unstimulated $\mathrm{T}$ lymphocytes displayed no evidence for apoptosis. In contrast, significant cleavage of PARP was observed, especially in stimulated T lymphocytes, but also in MOLT-4 and JURKAT cells (Figure 6A).

To elucidate whether caspases were involved in the apoptotic activity of BGT226 and Torin-2, we analyzed the effect of z-VAD-fmk, a broad-spectrum caspase inhibitor whose activity had been checked already in different cancer cells $[44,45]$. We administrated z-VAD-fmk alone and in combination with BGT226 or Torin- 2 for $24 \mathrm{~h}$ in stimulated T lymphocytes and MOLT-4 cells, then cells were analyzed by MTT assays. Results showed that z-VAD-fmk $(25 \mu \mathrm{M})$ alone had no relevant effect on cell viability, however when combined with BGT226 and Torin-2, it significantly inhibited apoptosis mediated by both drugs, in stimulated T lymphocytes and MOLT-4 cells. Thus, these findings indicated that BGT226 and Torin-2 induced a caspase-dependent apoptosis (Figure 6B).

We also measured caspase $3 / 7$ activation by enzymatic cleavage of the profluorescent substrate rhodamine 110, bis-N-CBZ-L-aspartyl-Lglutaml- L-valylL-aspartic acid amide (Z-DEVD-R110), with release of the intensely fluorescent rhodamine 110-cleaving group [46]. The activity of caspase $3 / 7$ was increased after drug treatment and was down-modulated by z-VAD-fmk (Figure 6C).

Furthermore, we studied drug-induced apoptosis using Annexin-V staining in stimulated T lymphocytes, MOLT-4 and JURKAT cell lines treated with BGT226 or Torin-2 for $24 \mathrm{~h}$. BGT226 effect was more relevant in MOLT-4 and stimulated T lymphocytes than in JURKAT cells, while the effect of Torin-2 was stronger in MOLT4 and JURKAT cells than in stimulated T lymphocytes (Figure 7A). The percentages of live, early and late apoptotic cells in response to treatment with BGT226 and Torin-2 $(0.1,0.25$ and $0.5 \mu \mathrm{M})$ are shown in Figure 7B.

\section{DISCUSSION}

Although preclinical studies have demonstrated that inhibition of $\mathrm{PI} 3 \mathrm{~K} / \mathrm{Akt} / \mathrm{mTOR}$ axis could be an effective strategy for targeted therapy of T-ALL $[47,48]$, it is still unclear which is the best target in this highly complex and branched signaling network. Pharmaceutical companies 
have synthesized a wide array of drugs, that target different components of this signaling parthway [49, 50]. This allows to envisage different strategies based on one side on the use of selective inhibitors displaying reduced adverse effects, and on the other side pan-inhibitors expected to exert a greater efficacy.

It has been recently documented that PI3K inhibitors were the most effective in inhibiting leukemic cell proliferation and survival in a panel of T-ALL human
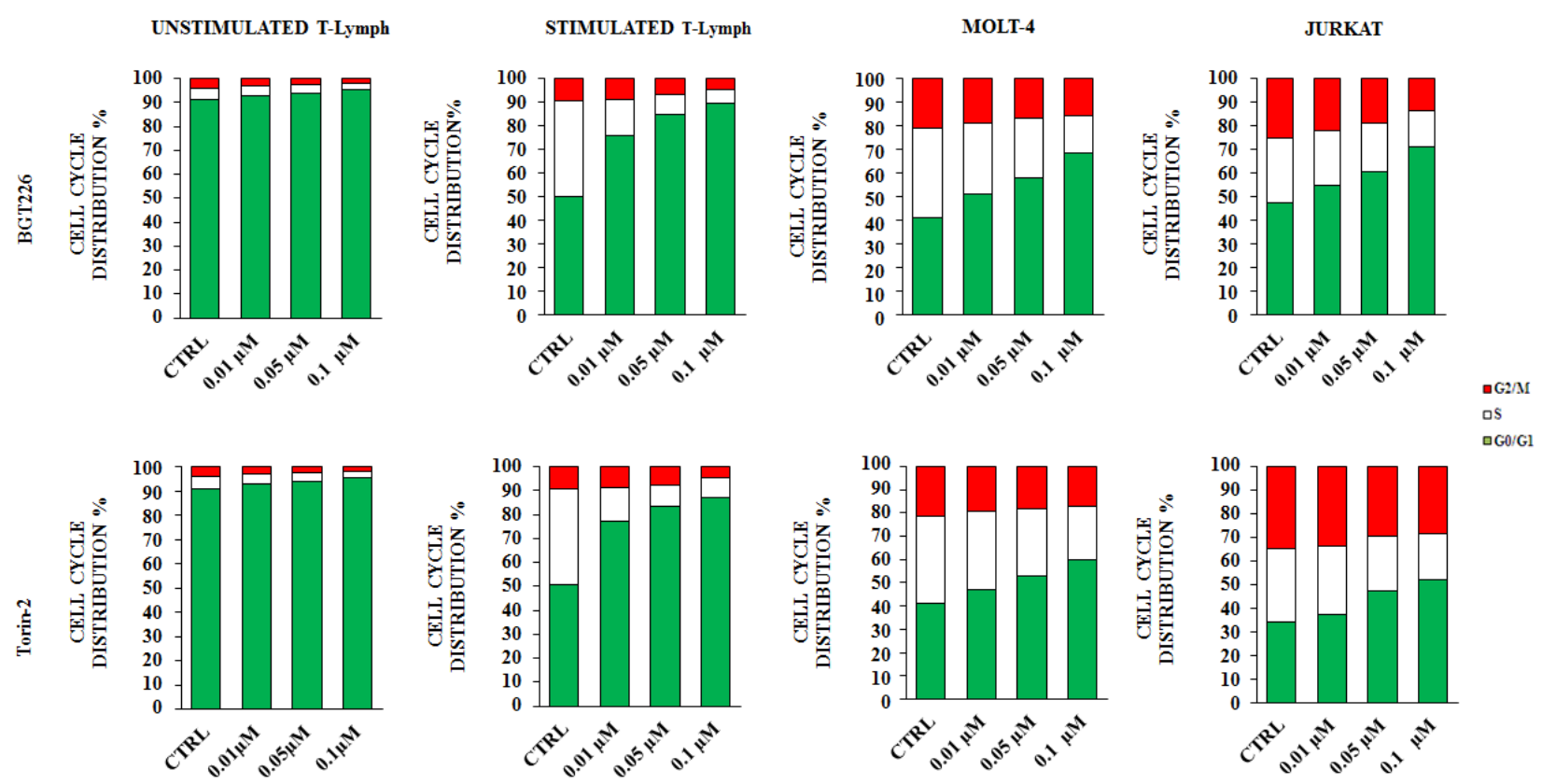

Figure 3: BGT226 and Torin-2 affect cell cycle in primary T lymphocytes, MOLT-4 and JURKAT cell lines. Unstimulated and stimulated T lymphocytes, MOLT-4 and JURKAT cells were treated with increasing concentrations of BGT226 and Torin-2 for 24 h. CTRL, control (untreated) cells. SD was less than $10 \%$.

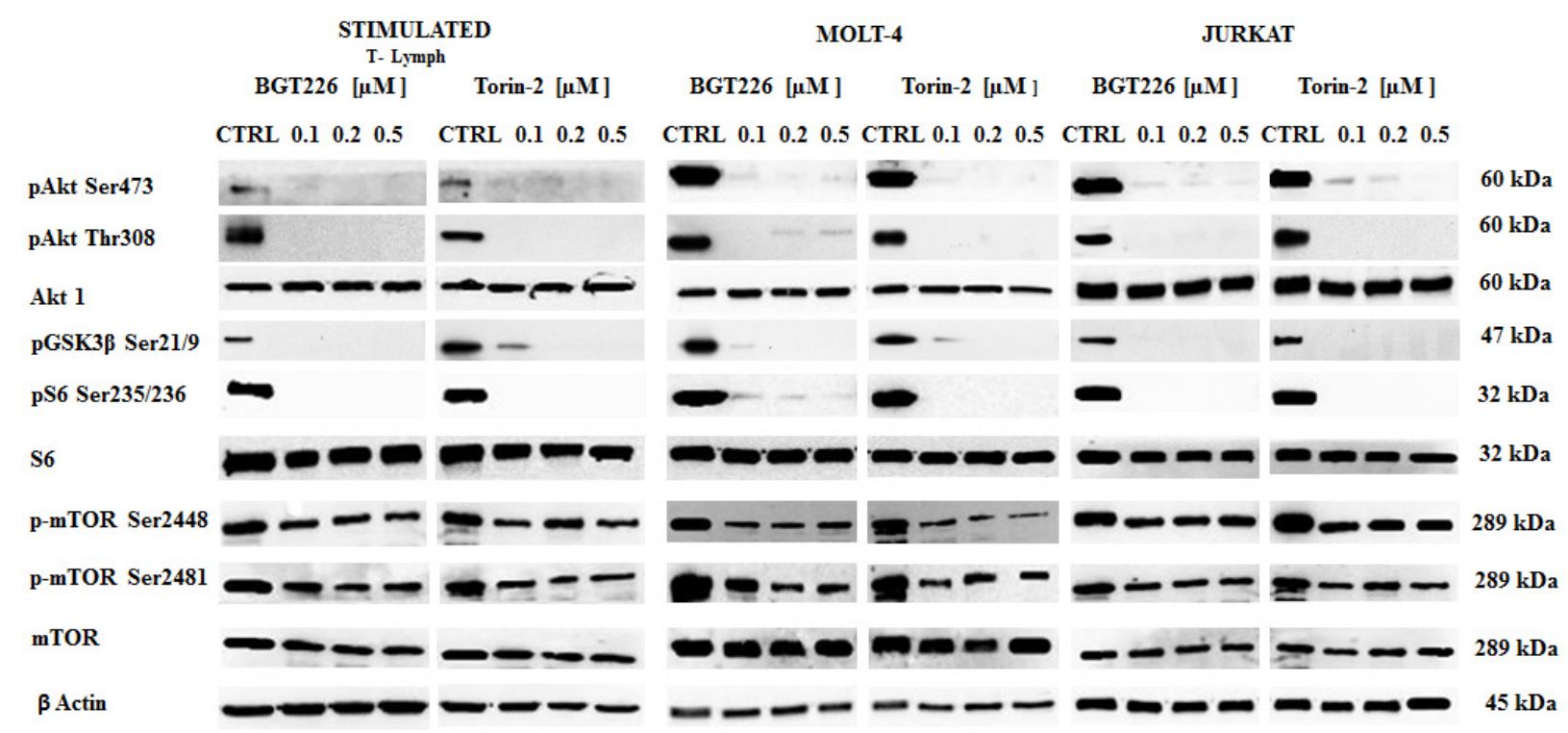

Figure 4: Expression and phosphorylation status of mTOR, Akt and their downstream targets in primary T lymphocytes and T-ALL cell lines. Western blot analysis of phosphorylated and total Akt, mTOR and their substrates GSK3 $\beta$ and S6 in stimulated T lymphocytes, MOLT-4 and JURKAT cells treated for $2 \mathrm{~h}$ with increasing concentrations of BGT226 and Torin-2. For all experiments twenty-five $\mu \mathrm{g}$ of protein was blotted on each lane. $\beta$-actin served as loading control. 
cell lines, irrespectively of PTEN status. These findings strongly supporting clinical application of class I PI3K pan-inhibitors rather than dual $\gamma / \delta$ or single-isoform inhibitors for treatment of the majority of T-ALL patients [51].

Nevertheless, the functions of the immune system cells could be impaired by these drugs. Here we evaluated the effects on human healthy $\mathrm{CD}^{+}$T-cells of four $\mathrm{PI} 3 \mathrm{~K} / \mathrm{Akt} / \mathrm{mTOR}$ inhibitors used as anticancer agents, to explore how these treatments could affect the patient immunological status.

No cytotoxic effects were displayed by the drugs on unstimulated $\mathrm{CD}^{+} \mathrm{T}$ lymphocytes, whereas all the inhibitors and particularly BGT226 and Torin-2 reached $\mathrm{IC}_{50}$ values in the nanomolar range in T-ALL cells.
In consideration of these findings, we performed the following sets of experiments using only BGT226 and Torin-2.

As to the cell cycle, since the unstimulated $\mathrm{CD}^{+} \mathrm{T}$ lymphocytes are mostly in a quiescent status, the drugs did not exert any effect, thus demonstrating the selectivity of the inhibitors.

In contrast, in either stimulated $\mathrm{CD}^{+} \mathrm{T}$-lymphocytes or MOLT4 and JURKAT cell lines, BGT226 and Torin-2 induced a concentration-dependent accumulation in the G0/G1 phase, and a concomitant decrease in S and G2-M phases, as reported by others [52-54].

As shown by Western blot, Torin-2 and BGT226 effectively blocked the phosphorylation of Akt Ser 473 and Thr308, GSK3 $\beta$ Ser21/9, mTORC1 Ser2448 and

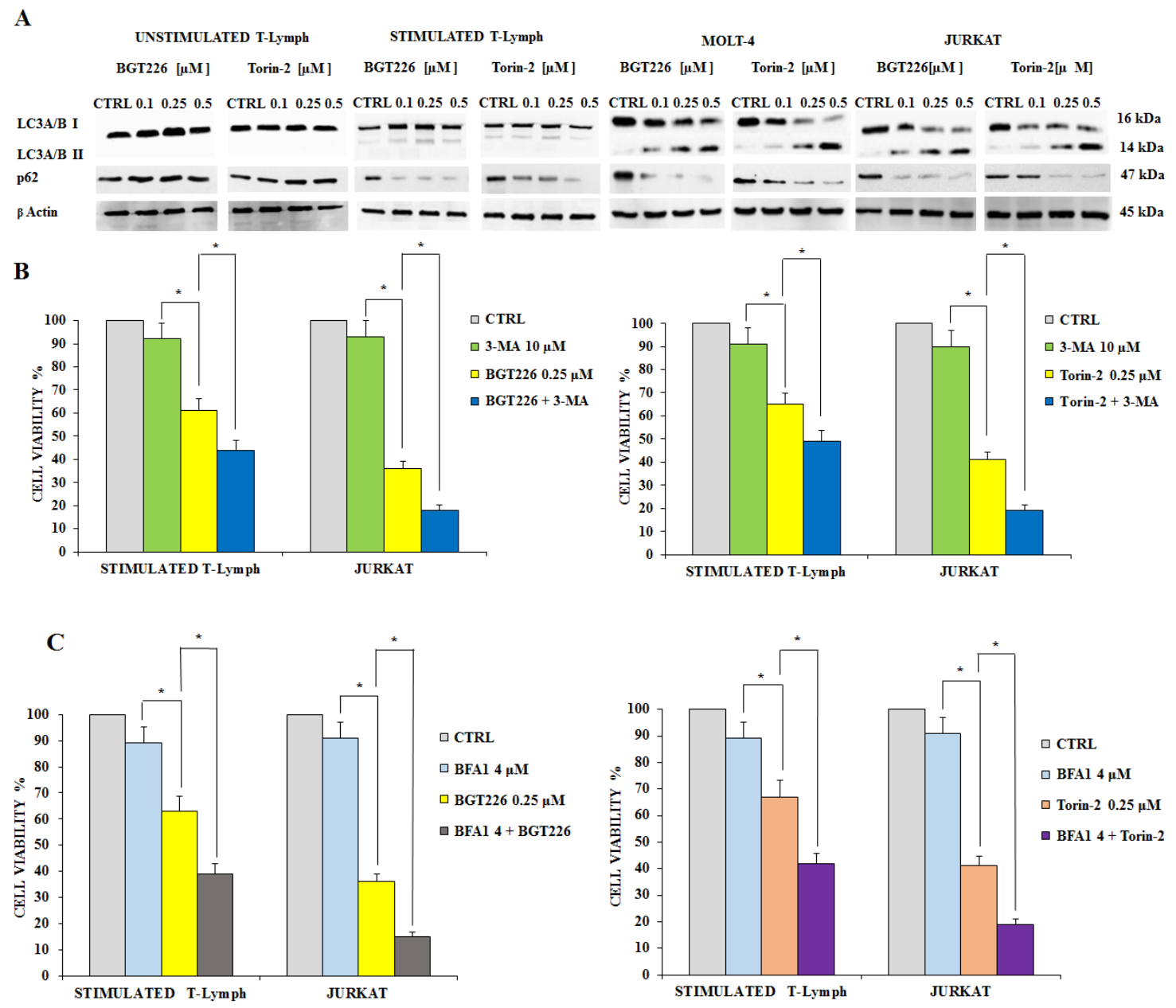

Figure 5: BGT226/Torin-2 induced autophagy in unstimulated, stimulated T lymphocytes and T-ALL cell lines. A. Western blot analysis of primary T lymphocytes and T-ALL cell lines treated for $24 \mathrm{~h}$ with increasing concentrations of BGT226 and Torin-2. An increase of expression of fast-migrating (lipidated) LC3A/B and a reduction of p62 in stimulated T lymphocytes, MOLT-4 and JURKAT cells is shown. Twenty-five $\mu \mathrm{g}$ of protein were blotted on each lane. $\beta$-actin documented equal lane loading. B. MTT assay documenting the effect of the autophagy inhibitor 3-MA (3-Methyladenine) on the viability of stimulated T lymphocytes and JURKAT cells treated for $24 \mathrm{~h}$ with BGT226 and Torin-2. C. MTT assay documenting the effect of the autophagy inhibitor Bafilomycin A1 on the viability of stimulated T lymphocytes and JURKAT cells treated for $24 \mathrm{~h}$ with BGT226 and Torin-2. Results are the mean of three different experiments $\pm \mathrm{SD}$. Asterisks indicate significant differences with respect to untreated cells $\left({ }^{*} \mathrm{p}<0.05\right)$. 
mTORC2 Ser2481. Furthermore, an mTORC1 downstream target, S6 protein, was fully dephosphorylated in both stimulated T lymphocytes and T-ALL cells.

Healthy unstimulated CD4 ${ }^{+} \mathrm{T}$ lymphocytes did not display induction of autophagy as documented by Western blot analysis of LC3A/B. Stimulated T lymphocytes appeared more sensitive to induction of autophagy when compared to unstimulated ones. We also documented that in leukemic cells the induction of autophagy was a protective mechanism, since cells incubated with autophagy inhibitors were less viable. Similar results were obtained in stimulated $\mathrm{T}$ lymphocytes.

The drugs also induced apoptosis in both stimulated $\mathrm{T}$ lymphocytes and leukemic cells. On the contrary, resting $\mathrm{T}$ lymphocytes did not undergo apoptosis. The apoptotic cell death was dependent on caspase activity. Therefore, apoptosis is one of the mechanisms that explain the cytotoxicity of these drugs.

It is now assumed that tumor growth and survival can be either promoted or restrained by immune system

A
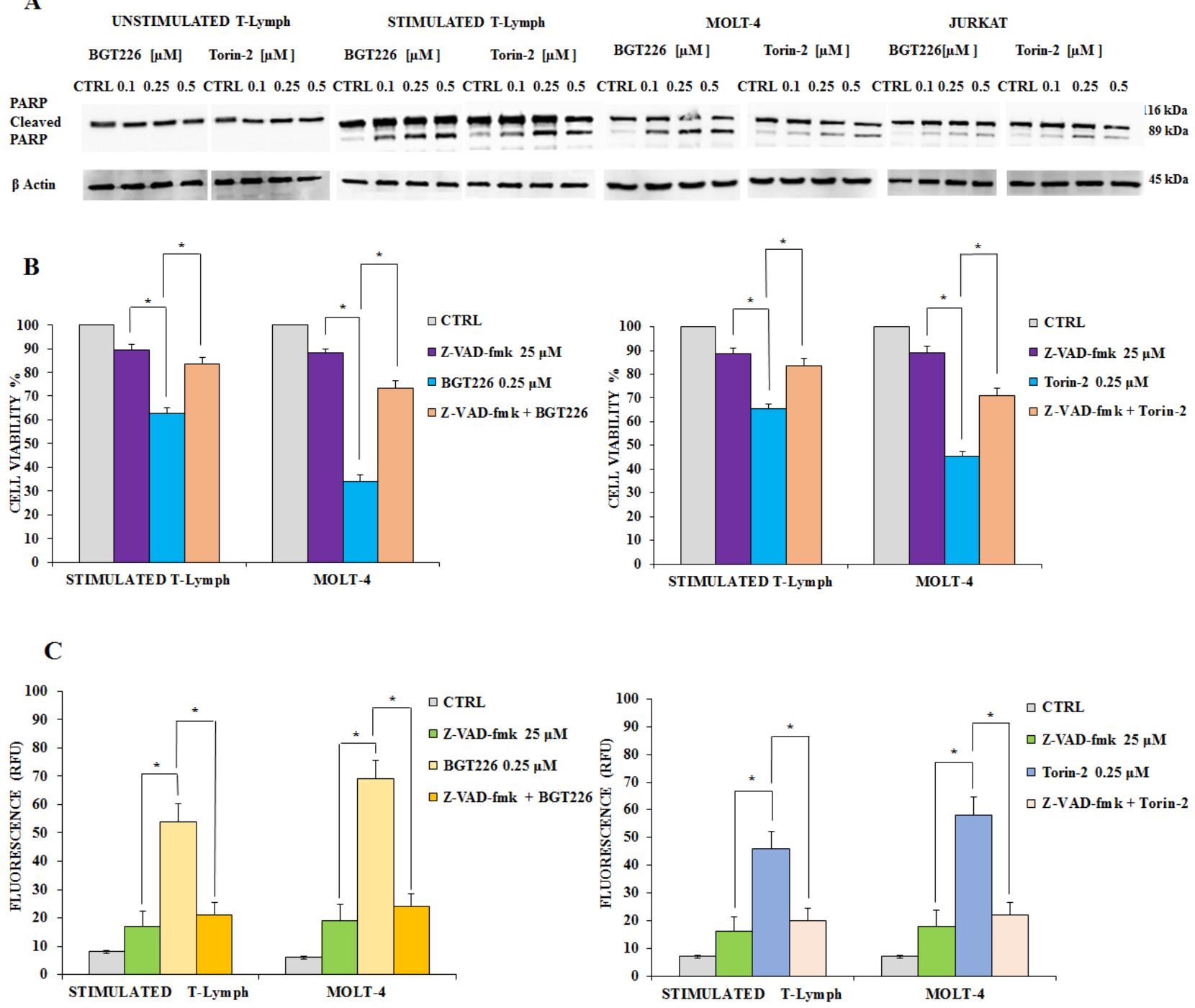

Figure 6: BGT226/Torin-2 induced autophagy in unstimulated, stimulated CD4 ${ }^{+}$T lymphocytes and T-ALL cell lines. A. Western blot analysis documenting the increase of PARP cleavage in stimulated T lymphocytes and T-ALL cell lines treated for $24 \mathrm{~h}$ with increasing concentrations of BGT226 and Torin-2. Twenty-five $\mu \mathrm{g}$ of protein was blotted on each lane. $\beta$-actin served as loading control. B. MTT assays after BGT226 and Torin-2 treatment, alone and in combination with the pan caspase inhibitor z-VAD-fmk, in stimulated T lymphocytes and MOLT- 4 cells. The analysis was performed after $24 \mathrm{~h}$ of treatment with BGT226 and Torin-2 at $0.25 \mu \mathrm{M}$ and z-VAD-fmk at $25 \mu \mathrm{M}$. C. enzymatic cleavage of the profluorescent substrate Z-DEVD-R110, with release of the intensely fluorescent rhodamine 110-cleaving group, after BGT226 and Torin-2 treatment, alone and in combination with the pan caspase inhibitor z-VAD-fmk, in stimulated T lymphocytes and MOLT- 4 cells. The analysis was performed after $24 \mathrm{~h}$ of treatment with BGT226 and Torin-2 at $0.25 \mu \mathrm{M}$ and z-VAD-fmk at $25 \mu \mathrm{M}$. Results are the mean of three different experiments $\pm \mathrm{SD}$. Asterisks indicate significant differences with respect to untreated cells $(* \mathrm{p}<0.05)$. 
A

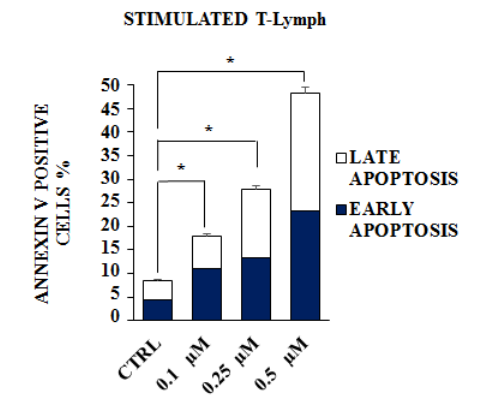

B

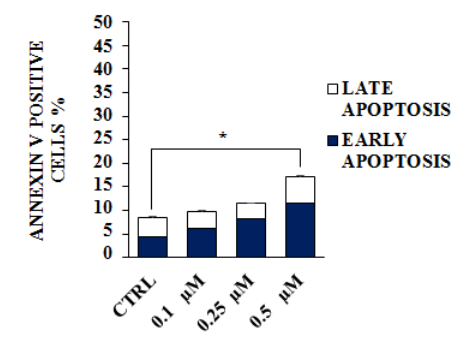

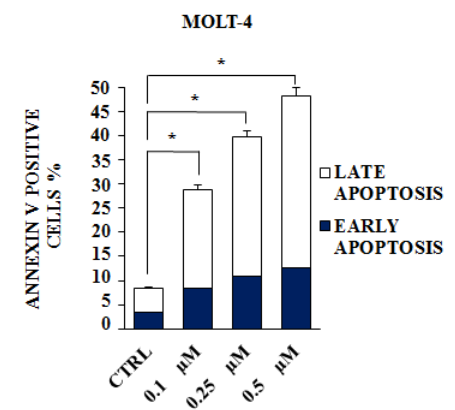
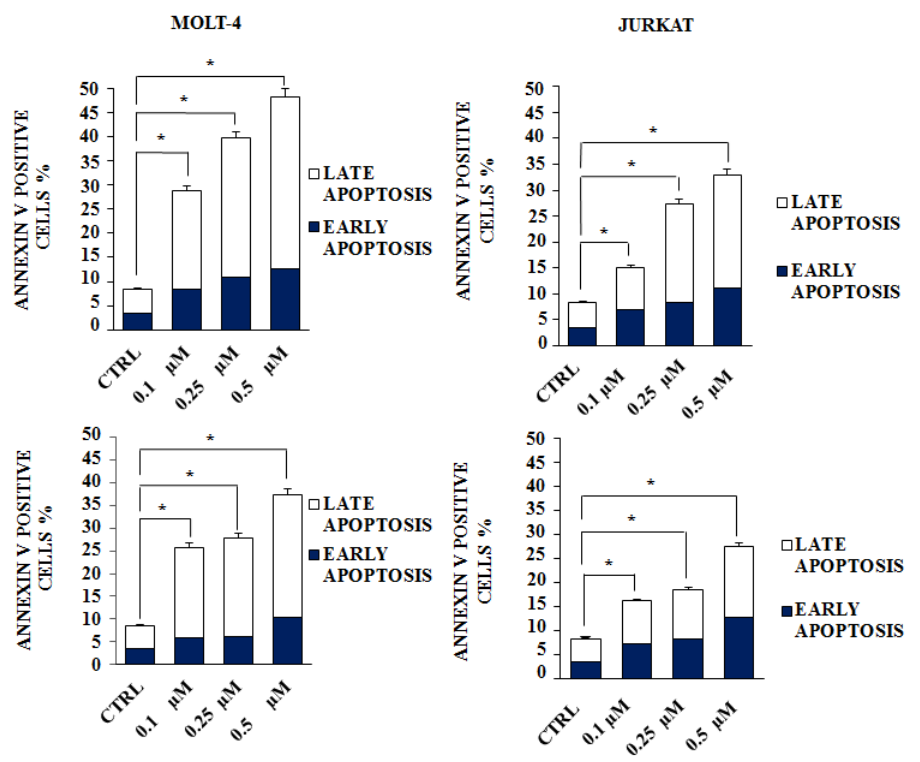
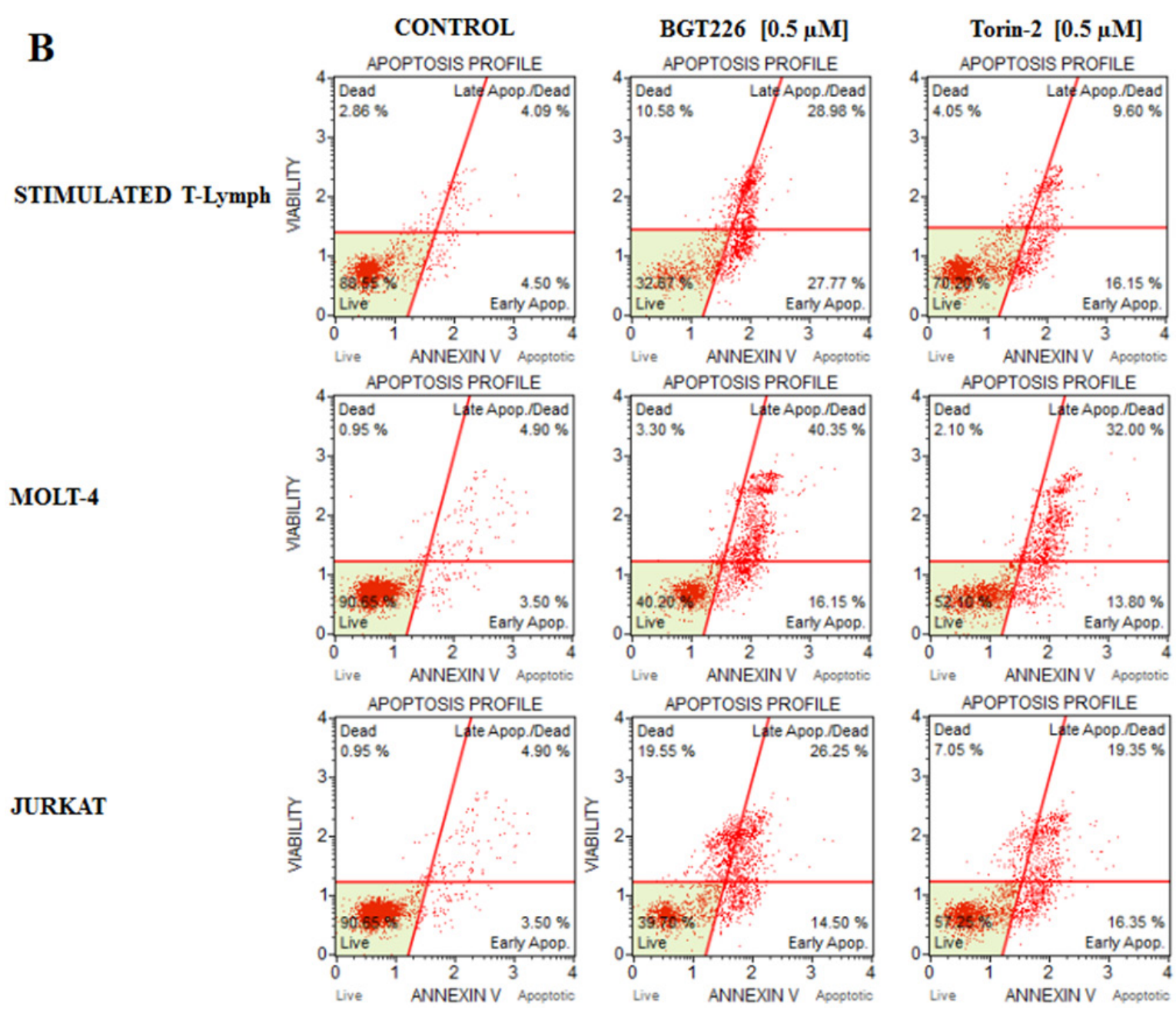

Figure 7: Flow cytometric analysis of drug-induced apoptosis. A. Analysis of Annexin-V positive cells after BGT226 and Torin-2 treatment using the Muse ${ }^{\mathrm{TM}}$ Cell Analyzer in stimulated CD4 ${ }^{+} \mathrm{T}$ lymphocytes, MOLT-4 and JURKAT cells. The analysis was performed after $24 \mathrm{~h}$ of treatment with increasing concentrations of the drugs. Results are the mean of three different experiments $\pm \mathrm{SD}$. B. Flow cytometric plots of Annexin V-FITC/PI stimulated T lymphocytes, MOLT-4 and JURKAT cells, treated with $0.5 \mu \mathrm{M}$ BGT226 and Torin-2. One representative of three different experiments that yielded similar results is shown. 
cells $[55,56]$. Therefore, it is critical to define whether novel anti-tumor drugs may impact on cells of the immune system. The ideal targeted therapy should specifically hit cancer cells and enhance anti-tumor immunity while preserving patient immunity [24].

It has been demonstrated that lymphocyte functions were minimally affected by $\mathrm{p} 110 \alpha$ inhibition both in vitro and in vivo. Although $\mathrm{p} 110 \alpha$ inhibition partially diminished Akt activation, it is likely that selective $\mathrm{p} 110 \alpha$ inhibitors will be less immunosuppressive in vivo than

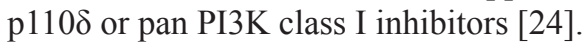

Natural killer cell-mediated cytotoxicity as well as antibody dependent cellular cytotoxicity against tumor cells were significantly impaired by pan class I PI3K inhibitors, whereas $\mathrm{p} 110 \alpha$ selective drugs had no effect $[51,57]$.

Other authors have shown recently that single inhibitors of class I PI3K isoforms in T-lymphocytes exerted a less potent impairment of T-cell activation than simultaneous inhibition of two or more isoforms [54]. These results suggest that complete blockade of class I PI3K activity strongly impairs T lymphocyte proliferation and activation in vitro.

In addition, it has been demonstrated that two ATPcompetitive PI3K pan-class I inhibitors, PX-866 and BKM120, showed differences in their ability to block T-lymphocytes proliferation and IL-2 secretion [26].

Nevertheless, these investigations were restricted only to pan class I PI3K isoform inhibitors and did not explore other drugs, such as Torin-2 and BGT226, which target to additional components of the PI3K/Akt/mTOR axis.

Therefore our data expanded the concept that targeted therapies, using different drugs against molecules at different levels of the PI3K/Akt/mTOR cascade, may be effective against tumor cells harboring aberrant upregulation of this signaling network, without affecting at the same time the immune system.

Given the commonly observed dysregulation of $\mathrm{PI} 3 \mathrm{~K} / \mathrm{Akt} / \mathrm{mTOR}$ pathway in T-ALL, the various types of single or dual pathway inhibitors under development might be effective in T-ALL treatment, provided that they do not affect the immune system. Therefore, the study of the effects of PI3K/Akt/mTOR inhibition not only in tumor cells, but in immune cells as well, may lead to selection of treatments that, while efficiently targeting deregulated $\mathrm{PI} 3 \mathrm{~K} / \mathrm{Akt} / \mathrm{mTOR}$ signals in tumor cells, preserve normal immune function, for appropriately tuning of personalized cancer therapy.

\section{MATERIALS AND METHODS}

\section{Materials}

RPMI-1640 medium, fetal bovine serum (FBS), penicillin and streptomycin were purchased from Lonza
Milano SRL (Milan, Italy). Torin-2, NVP-BGT226, MK2206 and ZSTK474 were obtained from Selleck Chemicals (Houston, TX, USA). For cell viability determination, Cell Proliferation Kit I (MTT) was purchased from Roche Applied Science (Basel, Switzerland). Annexin V/7ADD detection kit and cell cycle kits were from MerckMillipore (Darmstadt, Germany). For Western blot, antibodies to total Akt-1, Ser473 p-Akt-1 and Thr308 p-Akt-1 were from Santa Cruz Biotechnology (Santa Cruz, CA, USA), while all the other antibodies were from Cell Signaling Technology (Danvers, MA, USA), including the rabbit secondary antibody. The mouse secondary antibody, z-VAD-fmk, 3-Methyladenine (3- MA), Bafilomycin A1, Ficoll-Paque Plus and phytohemagglutinin were purchased from Sigma Aldrich (Milan, Italy). Dynabeads T-cell separation kit was from Invitrogen life Technologies (Monza MB, Italy). Signals were detected using ECL Plus reagent from Perkin Elmer (Boston, MA, USA).

\section{Cell culture and Western blot analysis}

\section{Cell lines}

T-acute lymphoblastic leukemia cell lines obtained from Deutsche Sammlung von Mikroorganismen und Zellkulturen GmbH (Braunschweig, Germany). JURKAT and MOLT-4 were maintained in RPMI-1640 medium supplemented with $10 \%$ heat-inactivated fetal bovine serum (FBS), 100 units $/ \mathrm{ml}$ penicillin and $100 \mathrm{mg} / \mathrm{ml}$ streptomycin at a density of 0.5 to $2 \times 10^{6}$ cells $/ \mathrm{ml}$ and were incubated at $37^{\circ} \mathrm{C}$ with $5 \% \mathrm{CO}_{2}$.

\section{Primary samples}

Peripheral Blood CD4+ T lymphocytes from healthy donors were obtained with informed consent according to institutional guidelines and isolated with Ficoll-Paque and magnetic beads labelling protocols (Dynabeads, Monza MI, Italy). Whole blood or buffy coat were diluted with PBS containing $0.1 \%$ BSA and $0.6 \%$ Na-citrate or $2 \mathrm{mM}$ EDTA (without $\mathrm{Ca} 2+$ and $\mathrm{Mg} 2+$ ) in ratio 1:1. Thirty-five $\mathrm{ml}$ of the diluted sample were layered over $15 \mathrm{ml}$ of FicollPaque medium and centrifuged at $600 \mathrm{~g}$ for 40 minutes at $20^{\circ} \mathrm{C}$. The peripheral blood mononuclear cell (PMNC) layer was transferred to centrifuge tube containing three volumes of PBS and centrifuged at $100 \mathrm{~g}$ for 10 minutes at $20^{\circ} \mathrm{C}$. This step was repeated twice, supernatant was discarded and cells were suspended in complete RPMI1640 medium.

$500 \mu \mathrm{l}$ PMNC were transferred into a test tube, at a density of $5 \times 10^{7}$ cells $/ \mathrm{ml}$ supplemented with $100 \mu \mathrm{l}$ of heat inactivated FBS and antibody mix and incubated at $4^{\circ} \mathrm{C}$ for 20 minutes. Followed by addition of $4 \mathrm{ml}$ isolation buffer and centrifuged at $350 \mathrm{~g}$ at $4^{\circ} \mathrm{C}$ for 8 minutes. The supernatant discarded, and the pelleted cells were suspended in $500 \mu \mathrm{l}$ of isolation buffer, added with 500 $\mu l$ of pre-warmed dynabeads and incubated for $15 \mathrm{~min}$ at $20^{\circ} \mathrm{C}$. The cells bound to beads were resuspended using 
$4 \mathrm{ml}$ isolation buffer. The supernatant containing the human $\mathrm{CD}^{+} \mathrm{T}$ lymphocytes was obtained by placing the resuspended cells in magnet for 2 minutes. The human $\mathrm{CD}^{+} \mathrm{T}$ lymphocytes were grown in complete RPMI-1640 medium with $10 \mu \mathrm{g} / \mathrm{ml}$ phytohemagglutinin at a density of $1 \times 10^{6}$ cells $/ \mathrm{ml}$, in a $\mathrm{CO}_{2}$ incubator at $37^{\circ} \mathrm{C}$ for $24 \mathrm{~h}[58$, 59].

\section{Western blot}

The cells were homogenized for $30 \mathrm{~min}$ in cold lysis buffer (50 mM Hepes $\mathrm{pH} 7.5,5 \mathrm{mM}$ EDTA $\mathrm{pH}$ 8.0, $10 \mathrm{mM} \mathrm{MgCl} 2,150 \mathrm{mM} \mathrm{NaCl}, 50 \mathrm{mM} \mathrm{NaF}, 20$ $\mathrm{mM} \beta$-glicerophosphate, $0.5 \% \mathrm{NP} 40,0.1 \mathrm{mM}$ sodium orthovanadate, $1 \mathrm{mM}$ PMSF, $1 \mathrm{mM}$ DTT) containing the protease inhibitor cocktail obtained from Roche Applied Science Basel, Switzerland. Lysates were centrifuged in a Microfuge for $10 \mathrm{~min}$ at $4^{\circ} \mathrm{C}$ and $25 \mu \mathrm{g}$ of solubilized proteins were resolved by $10 \%$ or $12 \%$ SDS-PAGE [60, $61]$.

\section{Cell viability analysis}

MTT (3-[4,5-Dimethylthythiazol-2-yl]-2,5Diphenyltetrazolium Bromide) assays were performed to assess the sensitivity of cells to drugs, as described [62, $63]$.

\section{Cell cycle and apoptosis analysis}

Cell cycle analysis was performed using the Muse ${ }^{\mathrm{TM}}$ Cell Analyzer (Merck Millipore, Milan, Italy). Cells were harvested after $24 \mathrm{~h}$ of treatment with the drugs, centrifuged at $300 \mathrm{~g}$ for 5 minutes and washed with $1 \mathrm{x}$ PBS. The cells were then fixed with $70 \%$ cold ethanol for $3 \mathrm{~h}$ at $-20^{\circ} \mathrm{C}$, centrifuged at $300 \mathrm{~g}$ for $5 \mathrm{~min}$ and washed with 1x PBS. Each sample was then resuspended in 200 $\mu \mathrm{l}$ of Muse ${ }^{\mathrm{TM}}$ Cell Cycle reagent, incubated in the dark for $30 \mathrm{~min}$ at room temperature, and analyzed according to the manufacturer's instructions. The analysis of apoptosis was performed by Annexin V/7-ADD-Assay. The cells treated with increasing concentrations of BGT226 or Torin- 2 were harvested after $24 \mathrm{~h}$. The cell suspension was labeled in the dark for 20 min with an equal volume $(100 \mu l)$ of the Muse $^{\text {TM }}$ Annexin-V Dead cell reagent (Merck Millipore). Subsequently, quantitative detection of Annexin-V/7AAD positive cells was performed using the Muse ${ }^{\mathrm{TM}}$ Cell Analyzer.

\section{Caspase-3/-7 activity assay}

Caspase activity was measured with the ApoOne Homogeneous Caspase $3 / 7$ assay kit (Promega Corporation, Madison, WI, USA), according to the manufacturer's instructions. The induction of apoptosis and associated activation of caspases 3 and 7 were measured by enzymatic cleavage of the profluorescent substrate rhodamine 110, bis-N-CBZ-L-aspartyl-Lglutaml-
L-valyl-L-aspartic acid amide (Z-DEVD-R110), which releases the intensely fluorescent rhodamine 110 -cleaving group. Cells were seeded at a density of $1 \times 10^{5} / \mathrm{ml}$ and incubated in a 96-well plate in the presence or absence of drug for $48 \mathrm{~h}$. For cells treated with a combination of z-VAD-fmk and drugs, they were initially treated with $\mathrm{z}$-VAD-fmk for $4 \mathrm{~h}$ prior to the addition of drugs. 100 $\mu l$ of the homogeneous caspase-3/-7 reagent was added to each well and the reaction mixture was incubated for $2 \mathrm{~h}$ at room temperature. Fluorescence was measured at an excitation wavelength of $485 \mathrm{~nm}$ and an emission wavelength of $538 \mathrm{~nm}$. Results are expressed as relative fluorescence units (RFU).

\section{Statistical evaluation}

The data are presented as mean values from three separate experiments \pm SD. Data were statistically analyzed by a Dunnet test after one-way analysis of variance (ANOVA) at a level of significance of $\mathrm{P}<0.05$ vs control samples [64].

\section{ACKNOWLEDGMENTS}

This work was supported by a MIUR FIRB 2010 grant to SC (RBAP10Z7FS_002), by a MIUR PRIN-2009 grant to $\mathrm{SC}$ and by current research funds to GZ.

\section{CONFLICTS OF INTEREST}

The authors declare no conflicts of interest.

\section{REFERENCES}

1. Li X, Chen F, Zhu Q, Ding B, Zhong Q, Huang K, Jiang X, Wang Z, Yin C, Zhu Y, Li Z, Meng F. Gli-1/PI3K/ Akt/NF-kB pathway mediates resistance to radiation and is a target for reversion of responses in refractory acute myeloid leukemia cells. Oncotarget. 2016; 7:33004-33015. doi: 10.18632/oncotarget.8844.

2. Yuan TL, Cantley LC. PI3K pathway alterations in cancer: variations on a theme. Oncogene. 2008; 27:5497-5510.

3. Dan HC, Antonia RJ, Baldwin AS. PI3K/Akt promotes feedforward mTORC2 activation through IKKalpha. Oncotarget. 2016; 7:21064-21075. doi: 10.18632/ oncotarget.8383.

4. Dinner S, Platanias LC. Targeting the mTOR Pathway in Leukemia. J. Cell. Biochem. 2016.

5. Sarbassov DD, Guertin DA, Ali SM, Sabatini DM. Phosphorylation and regulation of Akt/PKB by the rictormTOR complex. Science. 2005; 307:1098-1101.

6. Bhojwani D, Pui CH. Relapsed childhood acute lymphoblastic leukaemia. The Lancet Oncology. 2013; 14:e205-217. 
7. Chen JY, Cheng YN, Han L, Wei F, Yu WW, Zhang XW, Cao S, Yu JP. Predictive value of K-ras and PIK3CA in nonsmall cell lung cancer patients treated with EGFR-TKIs: a systemic review and meta-analysis. Cancer Biol \& Med. 2015; 12:126-139.

8. Zhou L, Baba Y, Kitano Y, Miyake K, Zhang X, Yamamura K, Kosumi K, Kaida T, Arima K, Taki K, Higashi T, Imai K, Hashimoto D, et al. KRAS, BRAF, and PIK3CA mutations, and patient prognosis in 126 pancreatic cancers: pyrosequencing technology and literature review. Med Oncol. 2016; 33:32.

9. Yang SX, Polley E, Lipkowitz S. New insights on PI3K/Akt pathway alterations and clinical outcomes in breast cancer. Cancer Treat Rev. 2016; 45:87-96.

10. Samuels Y, Ericson K. Oncogenic PI3K and its role in cancer. Current opinion Oncol. 2006; 18:77-82.

11. Jaiswal BS, Janakiraman V, Kljavin NM, Chaudhuri S, Stern HM, Wang W, Kan Z, Dbouk HA, Peters BA, Waring P, Dela Vega T, Kenski DM, Bowman KK, et al. Somatic mutations in p85alpha promote tumorigenesis through class IA PI3K activation. Cancer Cell. 2009; 16:463-474.

12. Silva A, Yunes JA, Cardoso BA, Martins LR, Jotta PY, Abecasis M, Nowill AE, Leslie NR, Cardoso AA, Barata JT. PTEN posttranslational inactivation and hyperactivation of the PI3K/Akt pathway sustain primary T cell leukemia viability. J Clin Invest. 2008; 118:3762-3774.

13. Silva A, Girio A, Cebola I, Santos CI, Antunes F, Barata JT. Intracellular reactive oxygen species are essential for PI3K/Akt/mTOR-dependent IL-7-mediated viability of T-cell acute lymphoblastic leukemia cells. Leukemia. 2011; 25:960-967.

14. Liu Q, Wang J, Kang SA, Thoreen CC, Hur W, Ahmed T, Sabatini DM, Gray NS. Discovery of 9-(6-aminopyridin3-yl)-1-(3-(trifluoromethyl)phenyl)benzo[h][1,6]naphthyridin$2(1 \mathrm{H})$-one (Torin2) as a potent, selective, and orally available mammalian target of rapamycin (mTOR) inhibitor for treatment of cancer. J Med Chem. 2011; 54:1473-1480.

15. Liu Q, Xu C, Kirubakaran S, Zhang X, Hur W, Liu Y, Kwiatkowski NP, Wang J, Westover KD, Gao P, Ercan D, Niepel M, Thoreen CC, et al. Characterization of Torin2, an ATP-competitive inhibitor of mTOR, ATM, and ATR. Cancer Res. 2013; 73:2574-2586.

16. Katanasaka Y, Kodera Y, Yunokawa M, Kitamura Y, Tamura T, Koizumi F. Synergistic anti-tumor effects of a novel phosphatidyl inositol-3 kinase/mammalian target of rapamycin dual inhibitor BGT226 and gefitinib in non-small cell lung cancer cell lines. Cancer Lett. 2014; 347:196-203.

17. Markman B, Tabernero J, Krop I, Shapiro GI, Siu L, Chen LC, Mita M, Melendez Cuero M, Stutvoet S, Birle D, Anak O, Hackl W, Baselga J. Phase I safety, pharmacokinetic, and pharmacodynamic study of the oral phosphatidylinositol3-kinase and mTOR inhibitor BGT226 in patients with advanced solid tumors. Ann Oncol. 2012; 23:2399-2408.

18. Qi L, Toyoda H, Xu DQ, Zhou Y, Sakurai N, Amano K, Kihira K, Hori H, Azuma E, Komada Y. PDK1-mTOR signaling pathway inhibitors reduce cell proliferation in MK2206 resistant neuroblastoma cells. Cancer Cell Int. 2015; 15:91.

19. Hirai H, Sootome H, Nakatsuru Y, Miyama K, Taguchi S, Tsujioka K, Ueno Y, Hatch H, Majumder PK, Pan BS, Kotani H. MK-2206, an allosteric Akt inhibitor, enhances antitumor efficacy by standard chemotherapeutic agents or molecular targeted drugs in vitro and in vivo. Mol Cancer Ther. 2010; 9:1956-1967.

20. Cheng Y, Ren X, Zhang Y, Patel R, Sharma A, Wu H, Robertson GP, Yan L, Rubin E, Yang JM. eEF-2 kinase dictates cross-talk between autophagy and apoptosis induced by Akt Inhibition, thereby modulating cytotoxicity of novel Akt inhibitor MK-2206. Cancer Res. 2011; 71:2654-2663.

21. Tan S, Ng Y, James DE. Next-generation Akt inhibitors provide greater specificity: effects on glucose metabolism in adipocytes. Biochem J . 2011; 435:539-544.

22. Yaguchi S, Fukui Y, Koshimizu I, Yoshimi H, Matsuno T, Gouda H, Hirono S, Yamazaki K, Yamori T. Antitumor activity of ZSTK474, a new phosphatidylinositol 3-kinase inhibitor. J Natl Cancer Inst. 2006; 98:545-556.

23. Pinson JA, Zheng Z, Miller MS, Chalmers DK, Jennings IG, Thompson PE. L-Aminoacyl-triazine derivatives are isoform-selective PI3Kbeta inhibitors that target nonconserved Asp862 of PI3Kbeta. ACS medicinal chemistry letters. 2013; 4:206-210.

24. So L, Yea SS, Oak JS, Lu M, Manmadhan A, Ke QH, Janes MR, Kessler LV, Kucharski JM, Li LS, Martin MB, Ren P, Jessen KA, et al. Selective inhibition of phosphoinositide 3-kinase p110alpha preserves lymphocyte function. J Biol Chem. 2013; 288:5718-5731.

25. Reif K, Okkenhaug K, Sasaki T, Penninger JM, Vanhaesebroeck B, Cyster JG. Cutting edge: differential roles for phosphoinositide 3-kinases, p110gamma and p110delta, in lymphocyte chemotaxis and homing. J Immunol. 2004; 173:2236-2240.

26. Blanco B, Herrero-Sanchez C, Rodriguez-Serrano C, Sanchez-Barba M, Del Canizo MC. Comparative effect of two pan-class I PI3K inhibitors used as anticancer drugs on human $\mathrm{T}$ cell function. Int Immunopharmacol. 2015; 28:675-685.

27. Soond DR, Bjorgo E, Moltu K, Dale VQ, Patton DT, Torgersen KM, Galleway F, Twomey B, Clark J, Gaston JS, Tasken K, Bunyard P, Okkenhaug K. PI3K p110delta regulates $\mathrm{T}$-cell cytokine production during primary and secondary immune responses in mice and humans. Blood. 2010; 115:2203-2213.

28. Herman SE, Gordon AL, Wagner AJ, Heerema NA, Zhao W, Flynn JM, Jones J, Andritsos L, Puri KD, Lannutti BJ, Giese NA, Zhang X, Wei L, et al. Phosphatidylinositol 3-kinase-delta inhibitor CAL-101 shows promising preclinical activity in chronic lymphocytic leukemia by antagonizing intrinsic and extrinsic cellular survival signals. Blood. 2010; 116:2078-2088. 
29. Liu F, Fan X, Auclair S, Ferguson M, Sun J, Soong L, Hou W, Redfield RR, Birx DL, Ratto-Kim S, Robb ML, Kim JH, Michael NL, et al. Sequential Dysfunction and Progressive Depletion of Candida albicans-Specific CD4 T Cell Response in HIV-1 Infection. PLoS pathogens. 2016; 12:e1005663.

30. Chang KY, Tsai SY, Wu CM, Yen CJ, Chuang BF, Chang JY. Novel phosphoinositide 3-kinase/mTOR dual inhibitor, NVP-BGT226, displays potent growth-inhibitory activity against human head and neck cancer cells in vitro and in vivo. Clin Cancer Res. 2011; 17:7116-7126.

31. Baumann P, Schneider L, Mandl-Weber S, Oduncu F, Schmidmaier R. Simultaneous targeting of PI3K and mTOR with NVP-BGT226 is highly effective in multiple myeloma. Anti-cancer drugs. 2012; 23:131-138.

32. Simioni C, Cani A, Martelli AM, Zauli G, Alameen AA, Ultimo S, Tabellini G, McCubrey JA, Capitani S, Neri LM. The novel dual PI3K/mTOR inhibitor NVP-BGT226 displays cytotoxic activity in both normoxic and hypoxic hepatocarcinoma cells. Oncotarget. 2015; 6:17147-17160. doi: 10.18632/oncotarget.3940.

33. Simioni C, Neri LM, Tabellini G, Ricci F, Bressanin D, Chiarini F, Evangelisti C, Cani A, Tazzari PL, Melchionda F, Pagliaro P, Pession A, McCubrey JA, et al. Cytotoxic activity of the novel Akt inhibitor, MK-2206, in T-cell acute lymphoblastic leukemia. Leukemia. 2012; 26:2336-2342.

34. Simioni C, Martelli AM, Cani A, Cetin-Atalay R, McCubrey JA, Capitani S, Neri LM. The Akt inhibitor MK-2206 is cytotoxic in hepatocarcinoma cells displaying hyperphosphorylated Akt-1 and synergizes with conventional chemotherapy. Oncotarget. 2013; 4:14961506. doi: 10.18632/oncotarget.1236.

35. Cani A, Simioni C, Martelli AM, Zauli G, Tabellini G, Ultimo S, McCubrey JA, Capitani S, Neri LM. Triple Akt inhibition as a new therapeutic strategy in T-cell acute lymphoblastic leukemia. Oncotarget. 2015; 6:6597-6610. doi: 10.18632/oncotarget.3260.

36. Wang Y, Liu J, Qiu Y, Jin M, Chen X, Fan G, Wang R, Kong D. ZSTK474, a specific class I phosphatidylinositol 3-kinase inhibitor, induces G1 arrest and autophagy in human breast cancer MCF-7 cells. Oncotarget. 2016; 7:19897-19909. doi: 10.18632/oncotarget.7658.

37. Tasian SK, Teachey DT, Rheingold SR. Targeting the PI3K/ mTOR Pathway in Pediatric Hematologic Malignancies. Frontiers in oncology. 2014; 4:108.

38. Janes MR, Vu C, Mallya S, Shieh MP, Limon JJ, Li LS, Jessen KA, Martin MB, Ren P, Lilly MB, Sender LS, Liu Y, Rommel C, et al. Efficacy of the investigational mTOR kinase inhibitor MLN0128/INK128 in models of B-cell acute lymphoblastic leukemia. Leukemia. 2013; 27:586-594.

39. Rubinsztein DC, Codogno P, Levine B. Autophagy modulation as a potential therapeutic target for diverse diseases. Nat Rev Drug Discov. 2012; 11:709-730.
40. Gewirtz DA. The autophagic response to radiation: relevance for radiation sensitization in cancer therapy. Radiation research. 2014; 182:363-367.

41. Klionsky DJ. Stepping back from the guidelines: Where do we stand? Autophagy. 2016; 12:223-224.

42. Kampa-Schittenhelm KM, Heinrich MC, Akmut F, Rasp KH, Illing B, Dohner H, Dohner K, Schittenhelm MM. Cell cycle-dependent activity of the novel dual PI3KMTORC1/2 inhibitor NVP-BGT226 in acute leukemia. Mol Cancer. 2013; 12:46.

43. Simioni C, Cani A, Martelli AM, Zauli G, Tabellini G, McCubrey J, Capitani S, Neri LM. Activity of the novel mTOR inhibitor Torin-2 in B-precursor acute lymphoblastic leukemia and its therapeutic potential to prevent Akt reactivation. Oncotarget. 2014; 5:10034-10047. doi: 10.18632/oncotarget.2490.

44. Mu Q, Ma Q, Lu S, Zhang T, Yu M, Huang X, Chen J, Jin J. 10058-F4, a c-Myc inhibitor, markedly increases valproic acid-induced cell death in Jurkat and CCRFCEM T-lymphoblastic leukemia cells. Oncol Lett. 2014; 8:1355-1359.

45. Wallington-Beddoe CT, Hewson J, Bradstock KF, Bendall LJ. FTY720 produces caspase-independent cell death of acute lymphoblastic leukemia cells. Autophagy. 2011; 7:707-715.

46. Yang C, Choy E, Hornicek FJ, Wood KB, Schwab JH, Liu X, Mankin H, Duan Z. Histone deacetylase inhibitor PCI-24781 enhances chemotherapy-induced apoptosis in multidrug-resistant sarcoma cell lines. Anticancer Res. 2011; 31:1115-1123.

47. Zhao WL. Targeted therapy in T-cell malignancies: dysregulation of the cellular signaling pathways. Leukemia. 2010; 24:13-21.

48. Bressanin D, Evangelisti C, Ricci F, Tabellini G, Chiarini F, Tazzari PL, Melchionda F, Buontempo F, Pagliaro P, Pession A, McCubrey JA, Martelli AM. Harnessing the $\mathrm{PI} 3 \mathrm{~K} / \mathrm{Akt} / \mathrm{mTOR}$ pathway in T-cell acute lymphoblastic leukemia: eliminating activity by targeting at different levels. Oncotarget. 2012; 3:811-823. doi: 10.18632/ oncotarget.579.

49. Markman B, Dienstmann R, Tabernero J. Targeting the $\mathrm{PI} 3 \mathrm{~K} / \mathrm{Akt} / \mathrm{mTOR}$ pathway--beyond rapalogs. Oncotarget. 2010; 1:530-543. doi: 10.18632/oncotarget.188.

50. Chappell WH, Steelman LS, Long JM, Kempf RC, Abrams SL, Franklin RA, Basecke J, Stivala F, Donia M, Fagone P, Malaponte G, Mazzarino MC, Nicoletti F, et al. Ras/ Raf/MEK/ERK and PI3K/PTEN/Akt/mTOR inhibitors: rationale and importance to inhibiting these pathways in human health. Oncotarget. 2011; 2:135-164. doi: 10.18632/ oncotarget.240.

51. Lonetti A, Cappellini A, Sparta AM, Chiarini F, Buontempo F, Evangelisti C, Orsini E, McCubrey JA, Martelli AM. PI3K pan-inhibition impairs more efficiently proliferation and survival of T-cell acute lymphoblastic leukemia cell 
lines when compared to isoform-selective PI3K inhibitors. Oncotarget. 2015; 6:10399-10414. doi: 10.18632/ oncotarget.3295.

52. Chiarini F, Grimaldi C, Ricci F, Tazzari PL, Evangelisti C, Ognibene A, Battistelli M, Falcieri E, Melchionda F, Pession A, Pagliaro P, McCubrey JA, Martelli AM. Activity of the novel dual phosphatidylinositol 3-kinase/mammalian target of rapamycin inhibitor NVP-BEZ235 against T-cell acute lymphoblastic leukemia. Cancer research. 2010; 70:8097-8107.

53. Evangelisti C, Ricci F, Tazzari P, Tabellini G, Battistelli M, Falcieri E, Chiarini F, Bortul R, Melchionda F, Pagliaro P, Pession A, McCubrey JA, Martelli AM. Targeted inhibition of $\mathrm{mTORC} 1$ and $\mathrm{mTORC} 2$ by active-site mTOR inhibitors has cytotoxic effects in T-cell acute lymphoblastic leukemia. Leukemia. 2011; 25:781-791.

54. Blanco B, Herrero-Sanchez MC, Rodriguez-Serrano C, Sanchez-Barba M, Del Canizo MC. Profound blockade of $\mathrm{T}$ cell activation requires concomitant inhibition of different class I PI3K isoforms. Immun Res. 2015; 62:175-188.

55. Hanahan D, Weinberg RA. Hallmarks of cancer: the next generation. Cell. 2011; 144:646-674.

56. Vanneman M, Dranoff G. Combining immunotherapy and targeted therapies in cancer treatment. Nat Rev Cancer. 2012; 12:237-251.

57. Yea SS, So L, Mallya S, Lee J, Rajasekaran K, Malarkannan $\mathrm{S}$, Fruman DA. Effects of novel isoform-selective phosphoinositide 3-kinase inhibitors on natural killer cell function. PloS one. 2014; 9:e99486.

58. Balakrishnan K, Burger JA, Quiroga MP, Henneberg M, Ayres ML, Wierda WG, Gandhi V. Influence of bone marrow stromal microenvironment on forodesine-induced responses in CLL primary cells. Blood. 2010; 116:1083-1091.

59. Zhao Q, Wang PP, Huang ZL, Peng L, Lin C, Gao Z, Su $\mathrm{S}$. Tumoral indoleamine 2, 3-dioxygenase 1 is regulated by monocytes and $\mathrm{T}$ lymphocytes collaboration in hepatocellular carcinoma. Oncotarget. 2016; 7:1478114790. doi: 10.18632/oncotarget.7438.

60. Valenti F, Fausti F, Biagioni F, Shay T, Fontemaggi G, Domany E, Yaffe MB, Strano S, Blandino G, Di Agostino S. Mutant p53 oncogenic functions are sustained by Plk2 kinase through an autoregulatory feedback loop. Cell Cycle. 2011; 10:4330-4340.

61. Lu Y, Shi C, Qiu S, Fan Z. Identification and validation of COX-2 as a co-target for overcoming cetuximab resistance in colorectal cancer cells. Oncotarget. 2016; 7:6476664777. doi: 10.18632/oncotarget.8649.

62. Mitkevich VA, Petrushanko IY, Spirin PV, Fedorova TV, Kretova OV, Tchurikov NA, Prassolov VS, Ilinskaya ON, Makarov AA. Sensitivity of acute myeloid leukemia Kasumi-1 cells to binase toxic action depends on the expression of KIT and capital A, CyrillicML1-ETO oncogenes. Cell Cycle. 2011; 10:4090-4097.

63. Tomonari T, Takeishi S, Taniguchi T, Tanaka T, Tanaka $\mathrm{H}$, Fujimoto S, Kimura T, Okamoto K, Miyamoto H, Muguruma N, Takayama T. MRP3 as a novel resistance factor for sorafenib in hepatocellular carcinoma. Oncotarget. 2016; 7:7207-7215. doi: 10.18632/oncotarget.6889.

64. Sparta AM, Bressanin D, Chiarini F, Lonetti A, Cappellini A, Evangelisti C, Melchionda F, Pession A, Bertaina A, Locatelli F, McCubrey JA, Martelli AM. Therapeutic targeting of Polo-like kinase-1 and Aurora kinases in T-cell acute lymphoblastic leukemia. Cell Cycle. 2014; 13:2237-2247. 